\title{
Fenomena Penggunaan Akun Pseudonym dalam Memenuhi Motif Identitas Pribadi pada Pengikut Autobase@karawangfess di Twitter
}

\author{
Tetty Kris Setiana Panjaitan ${ }^{\mathrm{a}, 1^{*}}$, Yanti Tayo ${ }^{\mathrm{b}, 2}$, dan Flori Mardiani Lubis ${ }^{\mathrm{c}, 3}$ \\ a,b,c Universitas Singaperbangsa Karawang \\ Email: 'tettykrissetiana@gmail.com*; ${ }^{2}$ yanti.tayo@fisip.unsika.ac.id; dan ${ }^{3}$ flori.mardianilubis@staff.unsika.ac.id \\ * corresponding author
}

Keywords:

motive, pseudonym, twitter,

identity.

Kata Kunci:

motif, pseudonym, twitter, identitas

\begin{abstract}
This research is motivated by the phenomenon of the use of pseudonym accounts that have appeared on Twitter, individual identities in the real world are different from those shown in cyberspace, identities tend to change and can be created. Each individual must have a personal identity motive that encourages them to use the account. Based on the description above, the identification of the research problem is how the phenomenon of using a Pseudonym account on Twitter fulfills the motives of personal identity for its users. So this research aims to find out and describe the phenomenon of using Pseudonym accounts in fulfilling the motives of a user's personal identity on Twitter. The research method used is descriptive qualitative to present descriptions and provide explanations objectively with data collection techniques through observation, interviews, and documentation. The focus of this research is based on personal identity motives. The results of the study explain that by using a Pseudonym account, users feel like they really are, they don't need to ignore people from the real world. Users can express themselves freely without being disturbed so that whatever behavior they do doesn't need to feel restricted because the identity built into the Pseudonym account will not let other people know who the person behind the Pseudoym account is.
\end{abstract}

\begin{abstract}
ABSTRAK
Penelitian ini dilatarbelakangi oleh fenomena penggunaan akun Pseudonym yang banyak bermunculan di Twitter, identitas individu dalam dunia nyata berbeda dengan yang ditunjukan di dunia maya, identitas cenderung berubah serta dapat dibuat. Setiap individu pasti memiliki motif identitas pribadi yang mendorong mereka untuk menggunakan akun tersebut. Berdasarkan uraian di atas maka identifikasi masalah penelitian yaitu bagaimana fenomena penggunaan akun Pseudonym di Twitter memenuhi motif identitas pribadi bagi penggunanya. Sehingga penelitian ini bertujuan untuk mengetahui dan mendeskripsikan mengenai fenomena penggunaan akun Pseudonym dalam memenuhi motif identitas pribadi pengguna di Twitter. Metode penelitian yang digunakan adalah deskriptif kualitatif untuk menyajikan gambaran dan memberikan penjelasan secara objektif dengan teknik pengumpulan data melalui observasi, wawancara, dan dokumentasi. Fokus penelitian ini berdasarkan pada motif identitas pribadi. Hasil penelitian menjelaskan bahwa dengan menggunakan akun Pseudonym, pengguna merasa menjadi diri mereka yang sebenarnya, mereka tidak perlu menghiraukan orang-orang dari dunia nyata. Pengguna dapat berekspresi secara bebas tanpa merasa terganggu sehingga perilaku apa saja yang mereka lakukan tidak perlu merasa dibatasi karena identitas yang dibangun dalam akun Pseudonym tidak akan membuat orang lain mengetahui siapa orang dibalik akun Pseudoym tersebut.
\end{abstract}




\section{PENDAHULUAN}

Keberadaan akun Pseudonym di kalangan pengguna Twitter menjadi fenomena yang banyak bermunculan dan menarik perhatian khususnya pada pengikut autobase@karawangfess di Twitter, hal tersebut dibuktikan dengan hasil angket online yang telah disebar oleh peneliti kepada para pengikut autobase@karawangfess. Sebagian besar dari para penggunanya menampilkan identitas aslinya seperti nama asli atau nama panggilan, foto pengguna dan informasi diri lainnya. Namun di jejaring sosial ini, Twitter juga memberi kebebasan dan tidak melarang pengguna lainnya untuk menggunakan akun dengan nama samaran atau akun yang dianggap tidak jelas perihal identitas penggunanya, sehingga siapa pun bisa menggunakan nama apa saja yang mereka inginkan tanpa aturan terkait penggunaan nama di Twitter.

Menurut Rosenbach dan Schmund terdapat tiga kategori dalam penggunaan identitas di media seperti internet, diantaranya: penggunaan nama asli (orthonym), nama alias atau samaran (pseudonym) dan tanpa nama (anonym). Di beberapa referensi, anonym dan pseudonym tidak berbeda dan diartikan sama (Kalaloi, 2019).

Dalam dunia nyata identitas yang dimiliki oleh individu di mungkinkan dapat berbeda dengan identitas yang ditampilkan di dunia virtual. Pada era modern ini, identitas lebih bebas bergerak, cenderung berubah-ubah dan dapat dibuat, personal, berlipat ganda dan swa-refleksi. Setiap individu dapat membuat ulang dan memilih identitas seperti apa yang ingin ditampilkan ketika kehidupan individu berubah dan meluas (Kellner, 2010, p. 315).

Donath menyatakan bahwa dalam dunia maya identitas individu bersifat samar. Peran sosial dan kepribadian seseorang tidak dapat disamakan antara dunia nyata dengan dunia maya. Identitas dunia maya adalah bagaimana individu tersebut menampilkan diri nya kepada orang lain. individu dapat memilih, menentukan maupun membatasi apa saja yang ingin orang lain ketahui tentang dirinya (Damayanti \& Yuwono, 2013).

Berdasarkan uraian tersebut di atas menjelaskan bahwa seiring perkembangan internet menimbulkan kemunculan pengguna akun Pseudonym, melalui akun ini pengguna dapat membuat dan membangun karakter tersendiri yang berbeda dari karakter yang mereka miliki dalam kehidupan nyata atau tidak sesuai dengan karakter asli yang mereka tunjukan sehari-hari. Di setiap penggunaan akun tersebut pasti ada motif yang timbul dari dalam diri penggunanya untuk memenuhi kebutuhannya di internet khususnya melalui Twitter. Menurut McQuail, motif memiliki empat indikator, diantaranya adalah identitas pribadi, informasi, integrasi dan interaksi sosial, dan hiburan. Penggunaan media tidak terlepas dari kepuasan dari media yang digunakan. Lingkungan sosial dan psikologis mempengaruhi individu menggunakan media sebagai pemuasan kebutuhan (Utomo, 2013).

Para pengguna Twitter seringkali berinteraksi dengan pengguna lain atau mencari informasi melalui autobase. Autobase merupakan sebuah wadah yang memfasilitasi pengguna Twitter untuk mengirimkan pesan tanpa diketahui pengirimnya dengan mengirimkan direct message (DM) ke base dengan menggunakan kode tertentu atau dikenal dengan istilah menfess (mention confess) di mana menfess digunakan untuk menyatakan perasaan terpendam ataupun kebencian dan pesan akan otomatis di post tanpa memberitahukan identitas asli pengirim tweet tersebut. Seperti halnya pada autobase @)karawangfess. Pengguna dapat mengirimkan pesan apa saja yang mereka inginkan untuk memenuhi kebutuhannya dan melalui tweetnya ini pengguna lain dapat berinteraksi di dalam kolom reply-nya.

@ karawangfess merupakan autobase yang memfasilitasi pengguna Twitter tidak hanya pengguna yang berasal dari Karawang namun juga dari kota-kota lainnya. Alasan peneliti memilih autobase ini karena akun ini merupakan akun yang sangat populer di kalangan pengguna Twitter. Dari observasi yang peneliti lakukan dapat diketahui bahwa @ karawangfess menjadi pelopor autobase pertama yang berasal dari Karawang, sehingga dapat menghubungkan para pengguna Twitter yang beragam dan dari latar belakang yang berbeda untuk saling berinteraksi, baik melalui fitur pesan menfess (mention confess) yang tidak diketahui pengirimnya maupun dari kolom reply tweetnya (Twitter, n.d). Selain itu, peneliti juga melihat bahwa pengikut dariautobase@karawangfess begitu beragam, tidak hanya yang menampilkan identitas asli, namun juga tidak sedikit pengikut dari autobase@karawangfess ini yang menggunakan nama samaran dan menutup identitas asli mereka di akun yang mereka gunakan.

Berdasarkan data dari Hootsuite pada Januari 2020, Twitter menempati posisi platform media sosial paling aktif ke lima di Indonesia atau sebesar 56\% dari 160 juta pengguna aktif media sosial. Di posisi pertama ditempati oleh Youtube, disusul oleh WhatsApp, Facebook, dan Instagram (Kemp, 2020). Dari sekian banyak pengguna Twitter di Indonesia membuat penggunaannya pun menjadi beragam. Perhatian peneliti tertuju pada akun Pseudonym yang menjadi daya tarik bagi peneliti. Pseudonym atau dikenal Pseudonim yang dalam bahasa Indonesia berarti akun yang menggunakan nama samaran. Akun Pseudonym digunakan para penggunanya untuk menyembunyikan identitas yang sebenarnya dengan tidak menggunakan nama asli mereka.

Kehadiran Twitter dimanfaatkan para pengguna akun Pseudonym untuk berinteraksi dengan pengguna lainnya. Selain itu Twitter menjadi tempat untuk mereka menghabiskan waktu guna memenuhi kebutuhan lainnya seperti menulis kicauan dan berbagai aktivitas pribadinya di dunia virtual namun tetap dengan identitas diri yang disembunyikan. Melalui akun ini mereka membuat dan membangun karakter tersendiri yang berbeda dari karakter yang mereka miliki dalam kehidupan nyata mereka atau bahkan tidak sesuai dengan karakter asli yang mereka tunjukkan sehari-hari. 
"Twitter doesn't block or ban users for having pseudonyms the way Google and Facebook do. Because Twitter realizes it can provide plenty of value for users (and thus for advertisers) without having to know your real name. The social web is about reputation and influence, not necessarily name." (Ingram, 2011).

Twitter tidak mempermasalahkan jika penggunanya menggunakan nama samaran dan tidak menggunakan nama yang sebenarnya atau menunjukan identitas aslinya. Tidak seperti platform jejaring sosial lain yang mengharuskan nama asli, Twitter memberikan kebebasan bagi penggunanya dalam mengakses Twitter sesuai keinginan dan kebutuhannya tanpa perlu menunjukan nama asli dari pengguna, karena Twitter menyadari bahwa hal tersebut memberi banyak nilai bagi penggunanya.

Di era modern, manusia lebih sering berkomunikasi dan berinteraksi melalui internet. Teknologi yang kian maju, internet yang semakin mudah untuk diakses dan situs jejaring sosial yang semakin beragam membuat manusia semakin dimudahkan untuk berkomunikasi lewat internet. Tidak hanya berkomunikasi dan berinteraksi yang dapat dilakukan melalui media internet tetapi juga dapat menjadi sarana untuk mencari dan mengonsumsi informasi-informasi yang diinginkan, menjadi tempat terbaik untuk mewujudkan hak atas kebebasan berekspresi, bahkan internet dapat menjadi ruang dan tempat bagi siapapun penggunanya untuk bisa mengkonstruksi diri menjadi siapapun yang dia mau. Keberadaan internet mendorong munculnya jejaring sosial yang memberikan ruang bagi penggunanya untuk dapat membangun identitasnya di dunia virtual.

Penelitian sebelumnya dari Syam \& Maryani (2019) mengenai Fenomena Pseudonim di Twitter mencoba memahami pandangan orang-orang beridentitas Pseudonim atau semu di Twitter melalui pengalaman mereka. Metode yang digunakan kualitatif dengan pendekatan fenomenologi. Hasil dari penelitian ini menunjukkan pemahaman pandangan mereka dapat diketahui melalui tiga discourses dalam media sosial: market discourse, play discourse dan social discourse. Makna pertama, media sebagai penyampai gagasan yang tidak dapat diungkapkan di luar cyber account, alat penghilang ketakutan terhadap pendapat orang di luar cyber account dan bentuk aktualisasi diri terhadap kehidupan sosial mereka. Makna kedua, memberikan pemahaman identitas pribadi, mendapatkan ilmu mengenai ketertarikan yang bisa di dapat di dunia cyber account, berinteraksi dengan sesama akun Pseudonim, mengisi waktu luang dan meluapkan emosi serta gagasan. Makna ketiga, konten cyber account yakni pencarian mutuals, tanya-jawab dan viral tweet di mana subjek merasa wajib untuk memberikan konten karena identitasnya. Identitas-identitas semu ini ada dan tidak mengubah para subjek, melainkan bentuk evolusi dari kesadaraan lalu diwujudkan dalam tindakan komunikasi.

Jika dibandingkan antara penelitian ini dengan penelitian Raina Islamita Syam \& Anne Maryani terdapat perbedaannya yaitu penelitian Raina Islamita Syam \& Anne Maryani menggunakan metode penelitian kualitatif dengan pendekatan fenomenologi sedangkan penelitian ini menggunakan metode penelitian kualitatif deskriptif. Penelitian ini lebih menjabarkan secara khusus pada motif identitas pribadi dari pengguna akun Pseudonym sedangkan penelitian Raina Islamita Syam \& Anne Maryani lebih kepada pemahaman pandangan orang-orang beridentitas pseudonim.

Berdasarkan uraian tersebut di atas maka tujuan dari penelitian ini adalah untuk mengetahui dan mendeskripsikan bagaimana fenomena penggunaan akun Pseudonym dalam memenuhi motifidentitas pribadi pada pengikutautobase@ karawangfess di Twitter serta menggali lebih dalam penggunaan akun Pseudonym dalam pemenuhan kebutuhan masingmasing penggunanya. Berdasarkan fenomena yang telah dipaparkan peneliti memutuskan untuk melakukan penelitian terkait fenomena penggunaan akun Pseudonym dalam memenuhi motif identitas pribadi pada pengikutautobase@ karawangfess di Twitter yang akan di pilih sesuai dengan kriteria yang telah ditetapkan oleh peneliti.

\section{TINJAUAN PUSTAKA}

Menurut Severin dan Tankard kehadiran dunia maya menciptakan suatu komunitas dunia maya. Komunitas dunia maya merupakan komunitas yang banyak muncul dalam dunia komunikasi digital daripada dunia nyata. Dapat dipahami bahwa komunitas dunia maya adalah kelompok-kelompok yang terdiri dari individu yang berkomunikasi dan menjalin interaksi melalui elektronik digital daripada secara langsung melalui tatap muka (Saifulloh \& Ernanda, 2018, p. 237).

Komunikasi melalui komputer (computer mediated communication) merupakan proses komunikasi yang menggunakan media komputer sebagai alat untuk berkomunikasi. Menurut John December, CMC didefinisikan sebagai suatu proses komunikasi melalui komputer dengan melibatkan manusia dalam berbagai situasi dan kondisi untuk mencapai berbagai macam tujuan melalui proses-proses penggunaan media oleh manusia (Tjahyana, 2007, p. 48).

Fenomena komunikasi melalui internet pada sekarang ini menjadi hal menarik bagi banyak orang, internet dijalankan sebagai akibat dari adanya penggunaan perangkat komputer. Komunikasi yang dilakukan manusia melalui internet telah berhasil membawa perubahan terhadap kehidupan manusia, khususnya komunikasi melalui jejaring sosial.

Menurut Barnes CMC mencakup teknologi yang memfasilitasi kemudahan berkomunikasi dan berbagi informasi secara interaktif melalui jaringan komputer. Twitter menjadi media yang dapat membantu para penggunanya untuk saling terhubung dengan pengguna lain secara luas melalui akun masing-masing pengguna agar dapat berinteraksi dan menciptakan sebuah hubungan komunikasi tanpa harus bertemu dan bertatap muka secara langsung. Selain itu, Twitter 
juga dapat menjadi media yang dapat memberikan dampak luas bagi penggunanya terutama pada kebutuhan akan informasi, pendidikan, hiburan dan lainnya (Adhrianti, 2014).

Jejaring sosial dapat menjadi sarana yang dapat digunakan oleh setiap orang untuk menjalankan peran sosial termasuk efek dan konsekuensi dari peran sosial tersebut di dunia maya. Karakteristik utama jejaring sosial yaitu pengguna dapat membentuk sebuah jaringan pertemanan, baik antara pengguna yang sudah diketahuinya di dunia nyata maupun membentuk jaringan pertemanan baru dengan orang asing di dunia maya (Nasrullah, 2015, p. 40).

Twitter adalah sebuah perusahaan dengan nama Twitter, Inc. yang juga merupakan sebuah media baru dengan menawarkan jejaring sosial berupa mikroblog yang dapat mempermudah para penggunanya untuk mengirim pesan, membaca pesan dan mendapatkan berita secara cepat dan mudah saat ini.

Menurut Zarella mikroblog merupakan bentuk blog dengan batasan jumlah teks dalam setiap kirimannya. Sebagai jejaring sosial yang menyediakan layanan mikroblog, Twitter memberikan fasilitas untuk menulis pesan dan penulisan tersebut hanya dapat menampung hinga 280 karakter yang biasa disebut dengan tweet atau kicauan (Harrera, 2016, p. 52).

Setiap individu pasti memiliki motif dalam menggunakan media. Motif adalah sebuah dorongan dan keinginan dari dalam diri manusia untuk menggerakan manusia untuk bertingkah laku disebabkan adanya berbagai macam kebutuhan yang ingin dipenuhi oleh setiap individu. Motif berasal dari bahasa latin movere yang memiliki arti yaitu to move atau bergerak, oleh sebab itu motif diartikan sebagai kekuatan dalam diri manusia yang mendorong manusia tersebut untuk berbuat (driving force) dan berperilaku.

Motif adalah alasan seseorang untuk melakukan sesuatu. Semua tingkah laku manusia didorong oleh motif-motif tertentu. Sigmund Freud mendefinisikan motif sebagai energi dasar yang mendorong tingkah laku manusia itu sendiri (Sardiman, 2007, p. 73).

Denis McQuail berpendapat bahwa motif-motif penggunaan media yaitu identitas pribadi, informasi, integrasi dan interaksi sosial serta hiburan. Setiap individu menggunakan media didasari karena adanya motif yang mendorong untuk memenuhi kebutuhan (Kriyantono, 2006, p. 213).

Seiring berkembangnya teknologi informasi dan komunikasi, pada saat ini manusia telah beralih ke media berbasis internet untuk memenuhi kebutuhan mereka. Jika dihubungkan dengan penelitian yang sedang diteliti maka dapat diartikan bahwa setiap individu mengakses jejaring sosial melalui internet didasari oleh motif atau alasan pengguna untuk memenuhi kebutuhannya. Oleh sebab itu penggunaan media internet yang dilakukan oleh manusia disesuaikan dengan tujuan dan kebutuhan yang timbul dari dalam diri manusia tersebut.

Dalam penelitian ini peneliti memfokuskan pada motif identitas pribadi dari penggunaan akun Pseudonym. Setiap individu dikatakan memiliki motif identitas pribadi apabila mereka ingin mencari dan menemukan berbagai hal yang menjadi penunjang nilai-nilai yang berhubungan dengan diri pribadi dan untuk mengenali pribadi melalui nilai-nilai lain yang ada dalam media serta ingin mendapat nilai lebih sesuai dengan statusnya. Oleh sebab itu alasan dan tujuan tertentu dari individu muncul sebagai motif dari penggunaan media.

Pseudonimitas menjadi fenomena penting di internet khususnya di Twitter. Pseudonym berasal dari bahasa Yunani Pseudo yang secara harfiah dapat diartikan sebagai nama samaran. Dalam Kamus Besar Bahasa Indonesia, Pseudonym atau Pseudonim memiliki arti yaitu nama yang digunakan seseorang seperti penulis, pengarang untuk menyembunyikan identitas sebenarnya atau disebut nama samaran. Asal muasal penggunaan kata Pseudonym menurut Room menyatakan bahwa nama samaran merupakan nama yang berbeda dengan nama yang sebenarnya dan dipahami sebagai nama lain yang digunakan seseorang untuk tujuan tertentu (Arifin, 2014, p. 24).

Di internet setiap individu bisa memiliki beberapa identitas berbeda dan dapat berubah. Ketika individu-individu membuat akun di jejaring sosial, ada beberapa pilihan yang dapat mereka ambil, seperti menggunakan akun Pseudonym di jejaring sosial menjadi sebuah pilihan bagi para penggunanya dengan adanya motif yang mendasari, sama halnya dengan pengguna lain yang memilih untuk menjadi pengguna jejaring sosial dengan identitas sesungguhnya. Semua tergantung pada tujuan para pengguna dalam membuat akun.

Dalam sudut pandang komunikasi, identitas dihasilkan melalui sebuah proses komunikasi dengan orang lain bukan dihasilkan secara sendiri. Dalam identitas yang menjadi prinsip utama adalah ketika pesan berubah diantara dua orang atau lebih, identitas dapat berubah-ubah dalam proses komunikasi karena tujuan dari identitas yaitu membangun sebuah komunikasi (Ayun, 2015, p. 3).

Pseudonimitas merupakan nama semu yang dibuat oleh seseorang. Pseudonim memungkinkan adanya keamanan dari identitas yang dimiliki individu serta terlindungi. Individu membangun identitas melalui nama dan foto semu yang bisa dirujuk pada tokoh kartun, idola, dan lainnya yang tidak berhubungan dengan identitas yang dimiliki individu sebenarnya (Fardiah, 2012). Nama samaran dibuat oleh pengguna internet dimungkinkan bukan hanya sekedar melindungi privasi akan identitas yang sebenarnya, lebih dari itu juga memungkinkan menjadi sebuah cara untuk mengekspresikan diri dan menciptakan kesan pertama. 


\section{METODOLOGI PENELITIAN}

Pendekatan kualitatif dipilih dalam penelitian ini dengan jenis penelitiannya adalah deskriptif. Metode penelitian kualitatif beralaskan pada filsafat post positivisme, metode penelitian digunakan untuk meneliti kondisi objek yang alamiah, teknik pengumpulan data dilakukan secara gabungan dan peneliti bertindak sebagai instrumen kunci, pengambilan sampel data dilakukan secara purposive, analisis data bersifat induktif atau kualitatif dan hasil dari penelitian kualitatif yaitu lebih menekankan kepada makna daripada generalisasi (Sugiyono, 2017, p. 15).

Penelitian kualitatif berusaha mengkonstruksi realitas dan memahami maknanya. Makna sendiri memiliki arti yaitu data yang sebenarnya. Menurut David Williams, menyatakan bahwa penelitian kualitatif dilakukan oleh peneliti yang tertarik secara alamiah dengan menggunakan metode alamiah dan pengumpulan data pada suatu latar alamiah (Arkandito et al., 2016).

Kemudian jenis penelitian deskriptif dipilih oleh peneliti sebab dapat memberikan gambaran serta mendeskripsikan mengenai suatu fenomena yang ada dengan menitik beratkan pada observasi dan suasana alamiah. Suasana alamiah dimaksudkan bahwa peneliti terjun ke lapangan. Menurut Sugiyono, metode penelitian jenis deskriptif menjadi salah satu metode penelitian yang paling banyak digunakan dalam sebuah penelitian yang bertujuan untuk menjelaskan dan menyajikan suatu gambaran dan kejadian dengan menggunakan prosedur ilmiah untuk menjawab masalah dengan cara sebenarnya (Sugiyono, 2009, p. 147). Metode ini digunakan untuk menjelaskan suatu fenomena dan menyajikan gambaran dan menjelaskan mengenai fenomena akun Pseudonym dalam memenuhi motif identitas pribadi pengguna di Twitter.

Teknik pengumpulan data merupakan langkah paling strategis ketika melakukan penelitian sebab tujuan yang utama dari sebuah penelitian adalah untuk mendapatkan data. Peneliti tidak akan mendapatkan data yang sesuai standar yang ditetapkan apabila peneliti melakukan penelitian tanpa mengetahui teknik pengumpulan data. Dalam penelitian ini terdapat tiga teknik pengumpulan data yang digunakan, yaitu observasi, wawancara, dan dokumentasi (Prasanti, 2018).

Dalam hal ini peneliti akan melakukan observasi pada informan yang dipilih sesuai dengan kriteria peneliti pada pengikutautobase@karawangfess yang menggunakan akun-akun Pseudonym sebagai fokus untuk memenuhi kebutuhan penelitian. Dalam penelitian ini peneliti melakukan observasi secara langsung berkaitan dengan akun Pseudonym yang digunakan oleh informan yang telah dipilih oleh peneliti untuk mengumpulkan data yang berkaitan dengan apapun yang dibutuhkan dalam penelitian ini. Observasi yang digunakan oleh peneliti adalah observasi partisipatif aktif, dalam artian peneliti terlibat dengan apa yang dilakukan oleh informan, tetapi belum sepenuhnya lengkap. Teknik wawancara yang dilakukan oleh peneliti dalam penelitian ini yakni melalui beberapa cara antara lain wawancara menggunakan telepon, wawancara melalui fitur chat dan voice note pada aplikasi WhatsApp, Line dan Telegram. Hal ini dilakukan karena beberapa hal yang menjadi pertimbangan seperti jarak, keterbatasan waktu informan dan ketidaksediaan informan untuk bertemu secara langsung dengan alasan privasi. Wawancara yang dilakukan mengikuti panduan wawancara yang telah disusun dan bisa saja mengajukan pertanyaan spontan yang masih berhubungan dengan masalah yang menjadi penelitian. Sehingga hasil dari wawancara tersebut bisa menjadi acuan dalam penyusunan penelitian. Dokumentasi yang diambil pada saat melakukan penelitian yaitu berupa hasil screenshot percakapan dan voice note di Whatsapp, Line dan Telegram antara peneliti dengan pengguna akun Pseudonym yang menjadi informan.

Pemilihan informan dilakukan dengan menggunakan teknik Purposive Sampling, dengan menentukan informan didasarkan pada pertimbangan tertentu, sehingga pemilihan informan karena dianggap benar-benar mengerti dan memahami sebuah penelitian agar dapat memberikan informasi terkait penelitian (Prasanti, 2018). Penelitian informan didasarkan pada pertimbangan peneliti, informan dipilih berdasarkan motif identitas pribadi yang ingin dipenuhi informan ketika menggunakan akun Pseudonym dengan mempertimbangkan pada kriteria tertentu. Kriteria dalam pemilihan informan yaitu pengguna akun Pseudonym di Twitter dan menjadi pengikut dari autobase@karawangfess, aktif mengelola akun Pseudonym, memiliki followers dan following minimal 100 dan bergabung di Twitter maksimal tahun 2019.

Sumber data yang digunakan untuk penelitian ini meliputi sumber data primer dan sumber data sekunder. Menurut Arikunto sumber data primer merupakan sumber data yang didapat langsung dari pihak pertama kepada peneliti seperti hasil wawancara atau hasil pengisian angket yang digunakan sebagai panduan untuk memperoleh data hasil penelitian melalui wawancara (Suharsimi, 2013, p. 172). Sedangkan data sekunder merupakan data yang dikumpulkan dari tangan kedua atau diperoleh secara tidak langsung dari sumber lain yang sudah tersedia sebelum penelitian dilakukan (Silalahi, 2012, p. 289).

Triangulasi digunakan dalam penelitian ini sebagai teknik untuk menguji keabsahan data. Menurut Patton menyebutkan bahwa triangulasi dapat dicapai dengan dengan membandingkan hasil pengamatan dalam penelitian dengan data hasil wawancara penelitian (Guzman \& Oktarina, 2018).

Peneliti menggunakan model analisis data interaktif Miles dan Huberman mengemukakan bahwa aktivitas dalam analisis data kualitatif dilakukan secara interaktif dan berlangsung terus menerus sampai tuntas, sehingga datanya sudah jenuh. Ukuran kejenuhan data ditandai dengan tidak diperolehnya lagi data atau informasi baru (Sugiyono, 2011, p. 246).

Aktivitas dalam analisis data, yaitu reduksi data, reduksi data berarti merangkum, memilih hal-hal pokok, memfokuskan pada hal-hal yang penting, dicari tema dan polanya. Data yang direduksi akan memberikan gambaran yang 
lebih jelas dan mempermudah peneliti untuk melakukan pengumpulan data selanjutnya dan mencarinya apabila diperlukan. Selanjutnya penyajian data, setelah data diolah dan direduksi maka data yang dihasilkan sesuai dengan maksud dan tujuan penelitian ini disajikan ke dalam teks yang bersifat naratif atau dalam arti menceritakan situasi sosial hasil penelitian yang telah dilakukan peneliti. Terakhir yaitu verifikasi, Kesimpulan awal yang dikemukakan masih bersifat sementara dan akan berubah apabila tidak ditemukan bukti-bukti kuat yang mendukung pada tahap pengumpulan data berikutnya. Tetapi apabila kesimpulan yang dikemukakan pada tahap awal, didukung oleh bukti-bukti yang valid dan konsisten saat peneliti kembali ke lapangan mengumpulkan data maka kesimpulan yang dikemukakan merupakan kesimpulan yang kredibel.

\section{HASIL PENELITIAN DAN PEMBAHASAN}

Dari hasil penelitian ini peneliti membahas dan memaparkan secara terperinci data yang didapat dari hasil penelitian mengenai fenomena penggunaan akun Pseudonym dalam memenuhi motif identitas pribadi pada pengikut autobase@ karawangfess di Twitter. Peneliti menjelaskan dan menganalisis data yang didapat dari penelitian yang dilakukan melalui observasi dan wawancara dengan informan melalui Twitter dan didukung oleh aplikasi Whatsapp, Line dan Telegram. Fokus penelitian yaitu membahas bagaimana fenomena penggunaan akun Pseudonym dalam memenuhi motif identitas pribadi pada pengikut autobase@karawangfess di Twitter.

Motif identitas pribadi merupakan motif untuk mencari hal-hal yang dapat menunjang perilaku maupun perbuatan pribadi dari individu dengan mengidentifikasi diri terkait nilai-nilai yang terdapat dalam media serta untuk meningkatkan pemahaman individu tentang dirinya sendiri dan membantu individu untuk menemukan sisi lain dari diri sendiri. Motif ini ditujukan sebagai penunjang karakteristik pribadi individu terkait penggunaan akun Pseudonym di Twitter.

Berdasarkan dari hasil wawancara penelitian yang dilakukan oleh peneliti terkait fenomena penggunaan akun Pseudonym dalam memenuhi motif identitas pribadi pada pengikut autobase@karawangfess di Twitter, hal pertama yang peneliti tanyakan kepada informan yaitu alasan mereka membuat akun Pseudonym dan menutup identitas asli mereka di akun tersebut. Kemudian para informan mengatakan alasan mereka membuat akun Pseudonym ini karena mereka membutuhkan kebebasan untuk mereka sendiri dalam mengekspresikan hal-hal yang mereka inginkan dan rasakan tanpa perlu merasa dibatasi oleh orang-orang yang mereka kenal dalam kehidupan nyata. Berikut ini pendapat yang diungkapkan dari para informan mengenai alasan mereka membuat akun Pseudonym:

Dalam wawancara yang dilakukan dengan Nuzul mengenai alasan dirinya membuat akun Pseudonym, ia mengungkapkan bahwa,

"Sebenernya aku termasuk orang yang sangat tertutup jadi dengan penggunaan akun pribadi yang bermutualan (berteman) dengan teman-teman dunia nyata emang bener-bener membatasi aku dalam melakukan apapun karena kaya biasanya kalo pake akun pribadi aku sendiri atau pake nama sendiri, aku reply an aja baik itu di base atau akun-akun lainnya itu agak sungkan karena nanti temen aku bisa tau apa yang aku reply kaya gitu. Sedangkan penggunaan akun Pseudonym sendiri jiwa-jiwa yang tertutup itu bisa bebas berekspresi jadi aku kaya mau reply apa aja bebas, mau sambat (berkeluh kesah) apa aja bebas, mau ngeluh apa aja di akun aku sendiri juga bebas karena temen-temen aku juga ga tau jadi ya bebas-bebas aja dan aku juga bermutualan dengan yang ga kenal jadi aku bisa cerita apapun tapi mereka ga akan tau tentang kehidupan aku gimana, misal tau cerita tapi ga tau kehidupan sebenernya gimana," (Nuzul, wawancara pribadi, 23 Juni 2020).

Hal yang sama peneliti tanyakan kepada Anissa, saat diwawancarai mengenai alasan dirinya membuat akun Pseudonym, menurutnya,

"Aku pilih buat nutup identitas tuh awalnya cuma buat sambat (berkeluh kesah) gitu, buat ngeluh-ngeluh, buat bikin status tanpa ketauan orang real gitu. Soalnya aku juga punya akun yang asli tapi itu isinya orangorang semua itu ga enak banget kaya kurang gimana ya, kaya kurang leluasa gitu lho. Soalnya selalu mikir ah pasti nanti dia komen pas ketemu langsung, ih dia ngeluh mulu gitu di Twitter, jadi aku milih bikin akun lagi yang isinya orang-orang yang aku ga tau, orang-orang yang aku ga usah temuin di dunia nyata gitu maksudnya, di langsung gitu," (Anissa, wawancara pribadi, 10 Juni 2020).

Sama hal nya seperti yang dituturkan oleh Dewi terkait dirinya membuat akun Pseudonym, ia membuat akun tersebut agar mempunya privasi untuk dirinya sendiri dan menghindari orang-orang terdekatnya mengetahui privasi nya memengenai keseharian dirinya di kehidupan nyata, tuturnya,

"Karena soalnya kan udah punya akun pake dengan identitas pribadi jadi nya pengen ngerasain punya akun yang bukan pake identitas pribadi dan pengen aja gitu punya akun yg orang-orang di real life atau di kehidupan aku tuh ga ada yg tau gitu kan aku juga punya privasi jadi aku privasi ga bisa dikasih tau sama orang orang di real life kan jadi aku limpahin nya ke sosial media. Nah kalo sosial media aku pake identitas pribadi otomatis orang di real life kan bakal tau kalo itu curhatan atau tentang aku jadinya memilih untuk membuat suatu akun tanpa identitas pribadi tuh alasannya untuk mempunyai privasi." (Dewi, wawancara pribadi, 14 Juni 2020). 
Menurut penuturan dari ketiga informan tersebut di atas bahwa akun Pseudonym yang mereka gunakan dapat berguna untuk menghindari teman-teman dari dunia nyata mereka. Dalam akun Pseudonym yang mereka gunakan, mereka lebih memilih untuk berteman dengan orang-orang baru di Twitter, karena dianggap lebih leluasa untuk mengungkapkan perasaan dan keluhan yang dialami karena teman-teman yang dikenalnya melalui Twitter pun tidak akan mengetahui kehidupan para informan yang sebenarnya, jadi dirasa tidak ada masalah yang begitu berarti.

Selanjutnya peneliti juga mewawancarai Yandika dan Sheryl. Mereka menuturkan pendapatnya terkait alasan mereka membuat akun Pseudonym. Yandika menuturkan bahwa dirinya membutuhkan tempat pelarian dan jika dirinya menggunakan akun dengan identitas sebenarnya, ia merasa canggung apabila dirinya ingin mencari teman baru pada akun tersebut. Berikut merupakan pernyataan yang diungkapkan masing-masing dari mereka. Menurut Yandika,

"Alasan pribadi kenapa membuat akun Pseudonym itu lebih ke arah ingin mencari pelarian aja dari dunia nyata, katakanlah misalnya jenuh dengan rutinitas yang ada atau ingin menambah teman dan tanpa memperlihatkan muka atau sekedar mencari teman ngobrol seketika malem saya lebih memilih penggunaan akun tersebut karena menurut saya identitas saya secara tidak langsung lebih aman, mungkin tidak 100\% aman namun menurut saya cukup oke. Waktu itu udah saya coba menggunakan akun pribadi saya yang utama itu untuk mencari teman tapi jatuhnya mungkin karena terlalu awkward mungkin ya kalo menurut saya jadi lebih memilih untuk menutupi identitas diri saja dibandingkan harus misalnya ketika saya menyapa seseorang yang belum dikenal dia melihat muka saya terus mungkin dia merasa saya mungkin kurang enak dipandang kali ya jadi beberapa orang memutuskan untuk tidak menggubris saya sedangkan jika menggunakan akun yang tidak menunjukan identitas asli sendiri pun jauh lebih aman mungkin secara perasaan saya." (Yandika, wawancara pribadi, 21 Juni 2020).

Sheryl juga menyatakan pendapatnya terkait dirinya membuat akun Pseudonym, menurut Sheryl,

"Soalnya aku ngerasa kalo kita pake nama samaran atau akun samaran gitu bisa nyaman aja jadi diri kita sendiri ga harus jaga hati orang deket atau orang yang kenal gitu. Bisa ngeluarin uneg-uneg diri sendiri aja di akun itu, suka-suka kita. Soalnya kan motivasi aku buat akun itu kan buat nyambat-nyambat (berkeluh kesah) bebas aja kaya kehidupan sehari-hari aja sambatan-sambatan biasa," (Sheryl, wawancara pribadi, 12 Juni 2020).

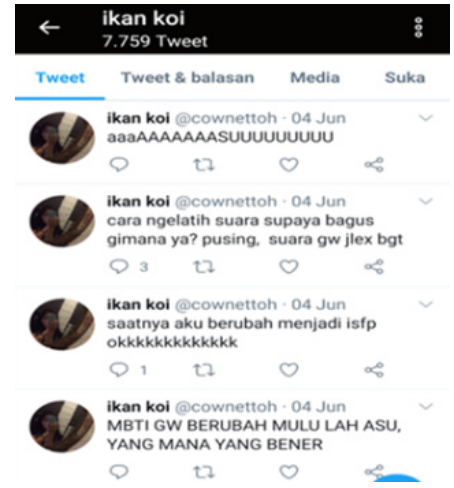

Gambar 2. Keluh Kesah di Akun Pseudonym (Twitter.com, n.d)

Para informan menyatakan bahwa alasan mereka membuat akun Pseudonym karena mereka bisa lebih leluasa dalam mengekspresikan diri maupun pendapat mereka seperti berkeluh kesah yang mengandung kata-kata kasar. Jika menggunakan akun dengan identitas asli, mereka beranggapan merasa tidak bebas dan sungkan jika ingin berpendapat, sehingga dirasa perlu untuk membuat akun baru tanpa menampilkan identitas pribadi mereka secara jelas agar merasa nyaman tanpa perlu memikirkan orang-orang dari kehidupan nyata mereka. Kemudian peneliti juga bertanya mengenai pengalaman dan perasaan mereka ketika menggunakan akun Pseudonym di Twitter, ketika menggunakan akun Pseudonym para informan merasa senang dan bebas tanpa merasa sungkan dengan pengguna Twitter lainnya. Berikut pernyataan yang diungkapkan oleh para informan: menurutnya

Neni menyampaikan pendapatnya mengenai pengalaman dan perasaan dirinya saat menggunakan akun Pseudonym,

"Kalo pengalaman dan perasaan sih ya seneng aja, apa lagi ada mutual sesama fandom jadi kalo ada kabar buruk atau bahagia jadi tau gara-gara timeline. Intinya kalo ada apa-apa tuh kaya paling up-to-date gitu dibanding jejaring sosial lain walaupun pake akun Pseudonym." (Neni, wawancara pribadi, 09 Juni 2020).

Delisa juga mengatakan pengalaman yang ia rasakan saat menggunakan akun Pseudonym miliknya,

"Pengalaman aku saat menggunakan akun Pseudonym itu kaya aku ngerasa lebih bebas berkomunikasi sama siapa aja dan ngobrolin apa aja gitu. Kalo aku pake akun aku yang asli, aku ga yakin bisa sebebas itu. Kalo di sini kan lebih bebas berkata-kata aja ga perlu jaim dan mikirin apa kata orang." (Delisa, wawancara pribadi, 11 Juni 2020). 
Menurut Neni dan Delisa saat mereka menggunakan akun Pseudonym mereka lebih bebas melakukan apa saja seperti berkomunikasi dengan siapapun tanpa perlu orang lain mempermasalahkan identitas mereka sebenarnya. Meskipun menggunakan akun Pseudonym, hal tersebut tidak menghalangi mereka untuk melakukan apa saja yang mereka sukai dan inginkan di akun tersebut. Mereka juga sangat senang dan merasa nyaman selama pengalaman mereka menggunakan akun Pseudonym di Twitter.

Hal yang berbeda juga diungkapkan oleh Naftalia dan Anissa mengenai pengalaman mereka menggunakan akun Pseudonym di Twitter. Naftalia merasa senang bisa mendapatkan banyak teman di akun Pseudonym namun disisi lain ia juga merasa terganggu dengan orang asing yang meminta nomornya yang dirasa cukup privasi bagi dirinya, Naftalia mengatakan bahwa,

"Kalo dari pengalaman aku ya aku jadi dapet temen banyak dari Twitter, dapet temen banyak banget, terus bisa sharing. Mungkin ada sih beberapa yang kaya ada strangers ga kenal terus tiba-tiba kaya nge dm langsung minta nomor wa atau segala macem itu kan aku risih banget ya karena orang ga kenal tiba-tiba kaya gitu cuman ya lebih banyak positif nya sih, aku bisa lebih banyak dapet temen, bisa saling sharing tentang perkuliahan atau tentang curhat lah saling curhat satu sama lain. Itu aja sih." (Naftalia, wawancara pribadi, 10 Juni 2020).

Penggunaan akun Pseudonym menjadi daya tarik tersendiri bagi para informan yang mengelolanya. Mereka merasa sangat nyaman dan lebih bebas sama hal nya seperti saat menggunakan akun yang menunjukkan identitas asli, hanya saja yang membedakan yaitu dari identitasnya. Selanjutnya peneliti juga menanyakan mengapa para informan memiliki lebih dari satu akun di Twitter selain akun Pseudonym dan apakah karakter yang ditunjukan dari masing-masing akun mereka berbeda. Berikut hasil wawancara antara peneliti dengan para informan terkait pernyataan mereka.

Delisa mengungkapkan alasan dirinya memiliki lebih dari satu akun selain akun Pseudonym karena dirinya ingin mempunyai teman dari sisi lain selain teman dari dunia nyata di akun pribadinya. Karakter yang ditampilkan dari masingmasing akun berbeda, jika di akun Pseudonym Delisa lebih menunjukan karakter diri sebagai wanita yang kesepian. Menurut Delisa,

"Aku punya dua akun Twitter dan di akun aku yang pertama itu akun real aku dan ya aku punya dua akun. Alasan punya lebih dari satu akun Twitter sih lebih ke pengen punya temen dari another side aja sih. Jadi another side yang aku maksud di sini itu yang mereka juga sejalan sama aku, ga mau nunjukin kenakalan mereka di depan temen-temen dunia nyata. Untuk karakter masing-masing akun cuma berbeda di bagian kenakalan nya aja sih menurutku. Nah kalo di akun Pseudonym aku, aku follow base-base yang postingannya selalu merujuk ke sex gitu dan aku lebih ke nakal tapi nunjukin juga karakter aku sebagai cewek yang kesepian karena emang aslinya aku tuh orangnya di depan temen-temen dunia nyata aja keliatan seneng aja, enjoy aja, padahal ga gitu. Di akun Pseudonym aku itu lah aku nunjukin ketidak enjoy an aku sama hidup aku." (Delisa, wawancara pribadi, 11 Juni 2020).

Kemudian hal yang sama diungkapkan oleh Nuzul dan Sheryl. Mereka memberikan pernyataan nya terkait pengalamannya yang memiliki akun lebih dari satu karena ingin menghindari teman-teman dari kehidupan nyata, berikut pernyataan dari Nuzul,

"Aku punya dua akun di Twitter yang pertama ada akun Pseudonym dan akun pribadi sendiri. Nah untuk mana yang lebih sering aku gunakan aku lebih sering gunakan akun Pseudonym sih sebenernya karena sebenernya dari dulu akun aku cuma satu yaitu aku Pseudonym dan suatu hari temen aku ngomong nih akun aku sendiri dan mereka pada follow karena mereka nyebarin dan temen-temen dunia nyata aku pada follow. Nah karena mereka pada follow juga dan aku ngerasa ga bebas aku buat akun baru khusus akun pribadi jadi aku blokir nih temen-temen aku dan aku pindahin ke akun pribadi jadi akun pribadi untuk mereka follow aja sih sedangkan aku ga main dan ga ngapa-ngapain juga emang lebih fokus di akun Pseudonym juga." (Nuzul, wawancara pribadi, 23 Juni 2020).

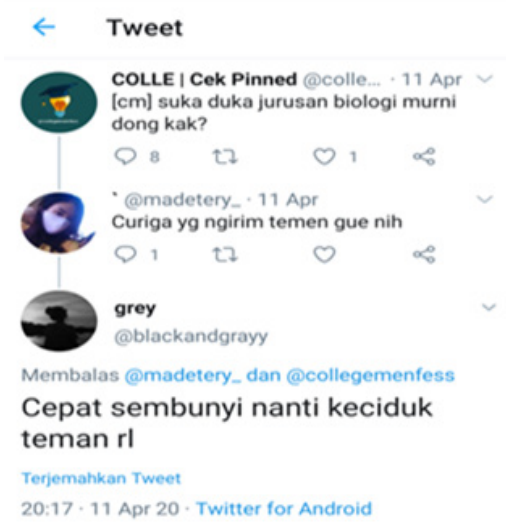

Gambar 3. Menghindari Teman Dunia Nyata (Twitter.com, n.d) 
Dari pernyataan yang diungkapkan oleh informan Delisa dan Nuzul bahwa dengan memiliki akun lebih dari satu, mereka tetap bisa berkomunikasi dengan teman yang mereka kenal di dunia nyata menggunakan akun pribadinya, sedangkan di akun Pseudonym mereka gunakan untuk mencari teman baru. Dengan adanya akun Pseudonym, mereka lebih merasa bebas menampilkan karakter dan sisi lain dari dirinya yang tidak bisa ditampilkan menggunakan akun dengan identitas pribadi. Selanjutnya peneliti menanyakan mengenai perbedaan yang didapat pada diri pribadi mereka ketika menggunakan akun Pseudonym dengan pribadi di kehidupan nyata. Berikut merupakan pernyataan hasil wawancara peneliti dengan para informan.

Neni mengungkapkan dirinya merasa lebih bisa mengekspresikan dirinya dibanding saat di dunia nyata, menurutnya.

"Jelas ada perbedaan, jujur ya aku kalo di dunia nyata introvert juga pemalu. Kecuali sama orang yang udah bener-bener deket baru lah barbar macam di akun samaran.” (Neni, wawancara pribadi, 09 Juni 2020).

Sedangkan Dewi mengungkapan bahwa dirinya tidak terlalu merasakan perbedaan terkait pribadinya di akun Pseudonym maupun di dunia nyata, meskipun ada, seperti yang dijelaskan oleh Dewi,

"Perbedaannya ga ada sih soalnya kan aku sesuai dengan karakter asli di real life ya jadinya ga ada yang beda semua masih sama kok. Paling lebih gampang berbaur sama stranger-stranger kalo pake akun Pseudonym, kalo di real life mau kaya gini masih mikir nih takutnya orang risih nih sama kita kalo misalnya kita tiba-tiba melakukan interaksi sama dia tapi kalo misalnya kita pake akun Pseudonym kita ga mikirin lagi dia risih apa engga." (Dewi, wawancara pribadi, 14 Juni 2020)

Kemudian Maharani merasakan lebih mudah untuk menuangkan segala permasalahan yang dihadapi ketimbang menceritakan nya dengan orang di dunia nyata, menurutnya,

"Yang aku rasain paling cuma ngerasa lega aja setiap ada masalah karena punya wadah untuk curhat sih. Kalo di dunia nyata emang aku agak susah buat cerita ke orang sekalipun orang deket gitu, kaya sungkan, takutnya cuma mau tau aja. Kalo di akun itu kan walaupun masalah ga terselesaikan setidaknya aku mudah mengeluarkan keluh kesah ngerasa lega juga udah ngeluarin curhatan aku di sana." (Maharani, wawancara pribadi, 11 Juni 2020)

Dari pernyataan yang sudah diuraikan tersebut di atas hampir semua informan merasakan perbedaan dalam dirinya ketika menggunakan akun Pseudonym dengan pribadi di kehidupan nyata mereka, meskipun beberapa dari mereka tidak merasakan perbedaan yang signifikan. Dari perbedaan yang mereka alami, mereka merasa lebih bisa mengekspresikan keadaan yang dialaminya di akun Pseudonym, karena akun tersebut dirasa bisa menjadi wadah mereka meluapkan perasaan dan emosi melalui teks yang mereka buat. Selanjutnya peneliti juga menanyakan jika dibandingkan dengan kehidupan nyata, apakah pada akun Pseudonym mereka merasa menjadi pribadi yang sesungguhnya. Berikut hasil wawancara peneliti dengan Delisa terkait pribadi yang sesungguhnya,

"Nah iya tuh, aku kalo lagi pake akun itu, aku ngerasa ya inilah gue yang sebenarnya gitu. Kalo di kehidupan nyata kan kaya ngerasa ga bebas aja, cuma nunjukin yang seneng dan enjoy nya aja padahal aku sendiri ga gitu sebenernya. Di akun ini lah aku bisa jadi apa adanya aku." (Delisa, wawancara pribadi, 11 Juni 2020).

Hal lain justru dinyatakan oleh Yandika, dirinya merasa tidak bisa menjadi pribadi yang sesungguhnya dalam akun Pseudonym karena ada hal yang masih ia tahan dalam dirinya, berbeda seperti yang dilakukan pengguna akun Pseudonym pada umumnya,

"Kalo ditanya apakah bisa menjadi pribadi yang sesungguhnya sebenarnya tidak bisa ya karena ada batasanbatasan tertentu yang membuat saya masih menahan beberapa bagian dari diri saya sehingga tidak 100\% sifat keaslian saya keluar di akun tersebut." (Yandika, wawancara pribadi, 21 Juni 2020).

Dari hasil wawancara peneliti dengan para informan, dapat disimpulkan bahwa ketika mereka menutup identitas pribadi mereka di akun Pseudonym, mereka ingin menyajikan gambaran diri dengan karakter sesungguhnya yang dimiliki oleh para informan. Penggunaan akun Pseudonym di Twitter membuat penggunanya merasa bebas jika dibandingkan dengan akun biasa yang menunjukkan identitas asli, mereka pun tidak perlu merasa dibatasi untuk melakukan apa saja yang mereka inginkan untuk dipenuhi karena orang lain pun tidak akan mengetahui siapa sebenarnya orang dibalik akun Pseudonym tersebut. Selama penggunaan akun Pseudonym, hampir semua informan menganggap bahwa mereka merasa menjadi pribadi yang sesungguhnya, karakter yang ditunjukan di akun Pseudonym dianggap sebagai cerminan dari diri mereka. Motif identitas pribadi menjadi hal yang sangat penting bagi mereka sebagai penunjang nilai-nilai pribadi yang ingin mereka sajikan lewat akun Pseudonym, hal tersebut mampu memberikan pemahaman diri bagi mereka secara pribadi. 
Jika dibandingkan hasil penelitian ini dengan hasil penelitian oleh Raina Islamita Syam \& Anne Maryani Mahasiswa dari Fakultas Ilmu Komunikasi Universitas Islam Bandung dengan penelitian berjudul "Fenomena Pseudonim di Twitter". Penelitian tersebut menunjukkan pemahaman pandangan pengguna akun pseudonim yaitu media sebagai penyampai gagasan yang tidak dapat diungkapkan di luar lingkup tersebut, alat penghilang ketakutan terhadap pendapat orang dan bentuk aktualisasi diri terhadap kehidupan sosial mereka. Selain itu memberikan pemahaman identitas pribadi. Identitas-identitas semu ini sebagai bentuk evolusi dari kesadaraan lalu diwujudkan dalam tindakan komunikasi.

Sedangkan penelitian ini lebih menjabarkan secara khusus pada motif identitas pribadi dari penggunaan akun Pseudonym bahwa motif identitas pribadi yang mendorong mereka menggunakan akun Pseudonym yaitu karena dari penggunaan akun Pseudonym dapat menyajikan gambaran diri dengan karakter sesungguhnya yang dimiliki oleh pengguna. Penggunaan akun Pseudonym di Twitter membuat penggunanya merasa bebas jika dibandingkan dengan akun biasa yang menunjukkan identitas asli, mereka pun tidak perlu merasa dibatasi untuk melakukan apa saja yang mereka inginkan untuk dipenuhi karena orang lain pun tidak akan mengetahui siapa sebenarnya orang dibalik akun Pseudonym tersebut. Hampir semua informan menganggap bahwa mereka merasa menjadi pribadi yang sesungguhnya, karakter yang ditunjukan di akun Pseudonym dianggap sebagai cerminan dari diri mereka. Motif identitas pribadi menjadi hal yang sangat penting bagi mereka sebagai penunjang nilai-nilai pribadi yang ingin mereka sajikan, hal tersebut mampu memberikan pemahaman diri bagi mereka secara pribadi. Mckenna dan Bargh (dalam Maulana, 2018) mengidentifikasi bahwa anonimitas atau pseudonimitas internet memungkinkan pengungkapan diri yang lebih besar karena mengurangi rasa risiko meskipun lebih lanjut disampaikan bahwa interaksi secara virtual jauh lebih mungkin untuk memberikan kepuasan instan dibandingkan dengan kegiatan sosial tatap muka.

\section{KESIMPULAN}

Berdasarkan pembahasan dari hasil penelitian yang telah diuraikan oleh peneliti sebelumnya dan berdasarkan motif identitas pribadi dari penggunaan media oleh Denis McQuail, teori ini dapat membantu untuk mendeskripsikan kebutuhan yang ingin dipenuhi oleh para informan melalui akun Pseudonym di Twitter. Peneliti telah menyimpulkan bahwa yang mendasari pemilik akun Pseudonym terkait fenomena penggunaan akun Pseudonym dalam memenuhi motif identitas pribadi pada pengikut autobase@karawangfess di Twitter yaitu karena mereka ingin menjalankan peran sosial dengan mencari ruang yang dapat memberikan kebebasan bagi mereka dalam berekspresi dan berperilaku namun tetap dalam kondisi yang aman dan nyaman. Mereka menyatakan bahwa dengan menggunakan akun Pseudonym mereka dapat memenuhi motif identitas pribadi dengan merasa menjadi diri mereka yang sebenarnya, mereka tidak perlu menghiraukan orang-orang yang berada dalam dunia nyata mereka, karena identitas yang dibangun dalam akun Pseudonym ini tidak akan membuat mereka dikenali oleh siapapun dan orang lain tidak akan mengetahui siapa orang dibalik akun Pseudoym tersebut, sehingga perilaku apa saja yang mereka lakukan tidak perlu merasa di batasi.

Berdasarkan kesimpulan dari hasil penelitian yang sudah diuraikan tersebut di atas oleh peneliti mengenai "Fenomena Penggunaan Akun Pseudonym dalam Memenuhi Motif Identitas Pribadi pada Pengikut Autobase@ karawangfess di Twitter", maka saran yang dapat diberikan oleh peneliti diharapkan dapat berguna dan bermanfaat dalam menggunakan media secara bijak dan tepat khususnya dalam penggunaan akun Pseudonym di Twitter, yaitu kebebasan dalam lisan maupun tulisan saat menggunakan akun dengan nama samaran yang tidak menunjukan identitas asli seperti penggunaan akun Pseudonym diharapkan dapat mengikuti etika dalam bermedia sosial ketika hendak berpendapat, berekspresi maupun berinteraksi dengan tetap menggunakan bahasa-bahasa yang sopan dan baik sesuai dengan ketentuan dan kebijakan baik yang dibuat oleh Twitter maupun peraturan negara dalam UU ITE. Sebisa mungkin untuk menghindari komentar kebencian ataupun komentar kasar di jejaring sosial demi kebaikan diri sendiri dan orang lain. Saat ini jejaring sosial banyak digunakan untuk berkarya dan mengembangkan kreatifitas para penggunanya, meski menggunakan akun Pseudonym, peneliti menyarankan untuk menciptakan sebuah kreatifitas dari konten-konten yang dibuat seperti hal-hal menghibur dan lain-lain karena banyak sekali hal positif yang bisa dilakukan ketimbang hanya melakukan hal-hal yang kurang bermanfaat.

\section{DAFTAR PUSTAKA}

[1] Adhrianti, L. (2014). Media Online dan Komunikasi Politik Tinjauan Teori Computer-Mediated-Communication (CMC) melalui media baru menuju kepentingan Pemilu 2014. Seminar Besar Nasional Komunikasi, $280-285$.

[2] Arifin, N. (2014). Fenomena Akun Pseudonym di Kalangan Pengguna Twitter Kota Makassar [Universitas Hasanuddin Makassar]. https://doi.org/10.4324/9781315853178

[3] Arkandito, G. F., Maryani, E., Rahmawan, D., \& Wirakusumah, K. (2016). Jurnal manajemen komunikasi. 1(1), 42-56.

[4] Ayun, P. Q. (2015). Fenomena Remaja Menggunakan Media Sosial dalam Membentuk Identitas. CHANNEL, 3(2), 1-16.

[5] Damayanti, M. N., \& Yuwono, E. C. (2013). Avatar, Identitas dalam Cyberspace. 15(1), 13-18. https://doi. org/10.9744/nirmana.15.1.113-18 
[6] Fardiah, D. (2012). INTERELASI PEREMPUAN DAN INTERNET. Observasi, 10(1), 1-12. https://doi. org/10.16309/j.cnki.issn.1007-1776.2003.03.004

[7] Guzman, K. C., \& Oktarina, N. (2018). Economic Education Analysis Journal. 7(1), 301-315.

[8] Harrera, A. E. P. (2016). Pemanfaatan Media Sosial Twitter oleh Ridwan Kamil dan Ganjar Pranowo Telah Sesuai dengan Fungsi Utama Media Massa. Jurnal The Messenger, 8(2), 52-60. https://doi.org/10.26623/themessenger. v8i2.335

[9] Ingram, M. (2011). Why Twitter doesn't care what your real name is. https://gigaom.com/2011/09/16/why-twitterdoesnt-care-what-your-real-name-is/

[10] Kalaloi, A. F. (2019). Media Sosial dan Keberanian Mengutarakan Pendapat di Era Kontemporer: Menelik Teori Spiral of Silence dalam Ruang Media Sosial. https://doi.org/10.31227/osf.io/p45f2

[11] Kellner, D. (2010). Budaya Media, Cultural Studies, Identitas, dan Politik; Antara Modern dan Postmodern. Jala Sutra.

[12] Kemp, S. (2020). Digital 2020: Indonesia. https://datareportal.com/reports/digital-2019-indonesia

[13] Kriyantono, R. (2006). Teknik Praktis Riset Komunikasi. Kencana Prenada Media Grup.

[14] Nasrullah, R. (2015). Media Sosial; Perspektif Komunikasi, Budaya, dan Sosioteknologi. Simbiosa Rekatama Media.

[15] Prasanti, D. (2018). Penggunaan Media Komunikasi Bagi Remaja Perempuan dalam Pencarian Informasi Kesehatan. Jurnal Lontar, 6(1), 13-21.

[16] Saifulloh, M., \& Ernanda, A. (2018). Manajemen Privasi Komunikasi pada Remaja Pengguna Akun Alter Ego di Twitter. WACANA, 17(2), 235-245.

[17] Sardiman, A. (2007). Interaksi dan Motivasi Belajar Mengajar. PT. Raja Grafindo Persada.

[18] Silalahi, U. (2012). Metode Penelitian Sosial. PT Refika Aditama.

[19] Sugiyono. (2009). Metode Penelitian Kombinasi (mixed method). Alfabeta.

[20] Sugiyono. (2017). Metode Penelitian Kuantitatif,Kualitatif dan R\&D. Penerbit CV Alfabeta.

[21] Suharsimi, A. (2013). Prosedur Penelitian: Suatu Pendekatan Praktik. Rineka Cipta.

[22] Syam, R. I., \& Maryani, A. (2019). Fenomena Pseudonim di Twitter: Studi Fenomenologi Konstruksi Identitas Cyber Account di Twitter. Manajemen Komunikasi, 5(2), 358-367. http://karyailmiah.unisba.ac.id/index.php/ mankom/article/view/16755/pdf

[23] Tjahyana, L. J. (2007). Teknologi Komunikasi 3G dari Sudut Pandang Computer Mediated Communication. Scriptura, 1(1), 48-59. http://cpanel.petra.ac.id/ejournal/index.php/iko/article/viewArticle/16675

[24] Twitter. (n.d). Hasil Observasi Penelitian. https://www.twitter.com

[25] Utomo, D. A. (2013). Motif Pengguna Jejaring Sosial Google+ di Indonesia. Jurnal E-Komunikasi, 1(3), $148-156$. 
